\title{
Chapter 11 \\ Biodiversity and Health in the Face of Climate Change: Implications for Public Health
}

\author{
Penny A. Cook, Michelle Howarth, and C. Philip Wheater
}

\begin{abstract}
A biodiverse natural environment is a health-promoting resource. A given habitat can simultaneously provide multiple ecosystem (and therefore health) benefits, both directly through, for example, flood risk mitigation and cooling, and indirectly as a resource for cultural and physical activities. The single biggest priority for public health is to work across governments and countries to protect biodiverse natural resources and introduce measures to stem climate change. At a more local level, public health professionals are responsible for devising strategies to promote sustainable lifestyles and facilitate access to natural environments. Modern public health emphasises the reduction of avoidable differences in ill health between the most and least well-off in society. Such strategies therefore need to target those from socio-economically deprived areas, who are most at risk of ill health. Schemes such as nature-based social prescribing or community referral give local commissioners of health services the opportunity to bring people into contact with nature. Those with responsibility for the provision of nature-based schemes should be encouraged to use interventions that bring people into active, rather than passive, contact with nature. Further, targeting such interventions towards exposure to environments with the greatest biodiversity is likely to offer the greatest benefits for human health.
\end{abstract}

Keywords Public health, biodiversity, climate change $\cdot$ Socio-economic status · Health inequalities · Nature-based social prescribing · Green care $\cdot$ Salutogenesis · Community referral $\cdot$ Asset based approach

\footnotetext{
P. A. Cook $(\bowtie) \cdot$ M. Howarth

School of Health and Society, University of Salford, Salford, UK e-mail: p.a.cook@salford.ac.uk; M.L.Howarth2@salford.ac.uk

C. P. Wheater

Faculty of Science and Engineering, Manchester Metropolitan University,

Manchester, UK

e-mail: p.wheater@mmu.ac.uk
} 


\section{Highlights}

- We consider the breadth of public health domains that are influenced by biodiversity.

- Existing models of greenspace and health are extended to look at the impact of biodiversity.

- Recommendations are provided for health professionals working from local to international levels.

- Nature-based social prescriptions or community referrals could maximise exposure to biodiversity.

- Case studies of health and biodiversity interventions for human and planetary health are presented.

\subsection{Introduction}

Public health is "the art and science of preventing disease, prolonging life and promoting health through the organised efforts of society" (Acheson 1988), and it focuses on the entire spectrum of health and well-being, not only the eradication of diseases. Public health activities can be targeted at both the population and the individual levels. Population-level interventions include those applied generally, such as a health campaign to increase knowledge and awareness of health risks or fluoridation of water supplies to reduce tooth decay, to those aiming to address the social, economic and environmental conditions that cause ill health, such as an urban regeneration project. Individual-level public health activities include personal services such as vaccinations, behavioural counselling and health advice. Non-medical interventions to individuals, which take place outside the clinical setting, and have a positive impact on health and well-being, also fall within the remit of public health. Such interventions include those promoting exposure to biodiverse environments.

Modern public health emphasises reducing avoidable differences in ill health between the most and least well-off in society (Acheson 1998; Marmot 2010). Morbidity and mortality rates are consistently and starkly higher among those with lower socio-economic status (SES) - typically 5-10 years' reduced life expectancy compared to those who are relatively more affluent (Marmot 2013; Elo 2009). Individuals of lower SES tend to live and work in less healthy environments and have higher exposure to disease risk factors; these are "social determinants of health" (Marmot and Wilkinson 2005). Moreover, lower SES is independently associated with a further 2-year reduction in life expectancy even after accounting for other risk factors for mortality, such as cardiovascular risk factors (Stringhini et al. 2017). The traditional approach to preventing disease - that is, counselling to reduce unhealthy behaviours - does not effectively address this phenomenon, because social and physical environments and circumstances mitigate behaviour change. Such inequalities are high on the political agenda (Marmot 2010, 2013; Marmot et al. 2008; Stringhini et al. 2017), and addressing the social determinants of health 
is an important and emerging area of clinical and public health practice (Axelson et al. 2018; Andermann 2016).

Reducing unhealthy behaviours requires the construction of supportive environments that facilitate healthier lifestyles. A biodiverse natural environment is a health-promoting resource (Lovell et al. 2014). More fundamentally, biodiverse environments are a foundation for human well-being and health, helping to sustain ecosystems that provide human health benefits, including within nutrition and medicine. A number of suggested conceptual and practical frameworks have been described that link ecosystem health and biodiversity with human health and wellbeing (Keune et al. 2013; Tzoulas et al. 2007, Fig. 11.1).

Biological diversity (biodiversity) is "the variability among living organisms from all sources including, inter alia, terrestrial, marine and other aquatic ecosystems and the ecological complexes of which they are part; this includes diversity within species, between species and of ecosystems" (United Nations Convention on

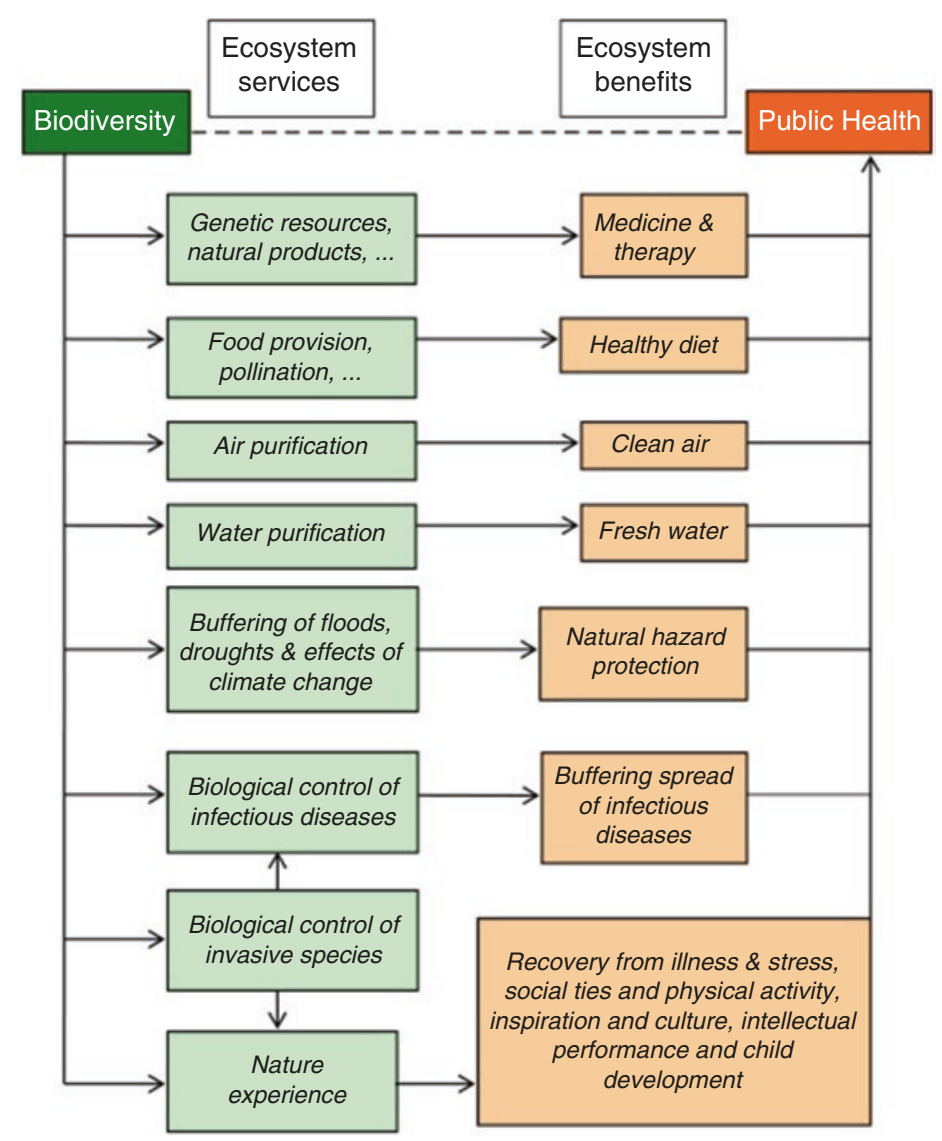

Fig. 11.1 Overview of the relationship between biodiversity and public health. (Source Keune et al. 2013) 
Biological Diversity 1992). Consequently, biodiversity can be categorised in many ways. Genetic diversity, although often not apparent visually, is arguably the fundamental level of biodiversity that underpins all the others. Where genetic variation is low, wildlife and agricultural populations tend to be less resilient to environmental changes including disease, pollution and the impacts of climate change. Within a single species, underlying genetic variation can be crucial in providing phenotypic (i.e. observable) differences. For example, the single species Canis lupus familiaris (domestic dog) provides a range of valuable attributes to benefit humans, including support for hearing, seeing, disease detection and companionship. Within species, there are less visible genetic differences; for example, individual street trees have differing levels of tolerance to pollution. Genetic diversity can also be important in providing sustainable crops and in moderating disease pathogens. For most people, morpho-species (organisms that look different from others) provide the basis for perceived species richness. The number, type and mixture of species (community structures) provide useful measures of richness at a fairly basic level.

At a broader level of diversity, organisms live in habitats that may form distinct entities, usually described in terms of their vegetation or physical characteristics (e.g. woodlands, grasslands, ponds, rivers). Habitats may be complex, featuring gradual horizontal transitions between different types (tall herbaceous vegetation merging into scrub and then becoming denser and taller woodland; open areas of water, becoming vegetated at the edges, merging into marshy areas and then wet grassland). Complexity is also increased by the vertical layers found within them (woodlands may feature ground vegetation, herbaceous layers, scrub, lower canopies of saplings, full canopies of mature trees and emergent trees that poke beyond the canopy).

\subsubsection{Chapter Overview}

Having introduced some key concepts, we summarise the linkages between public health and biodiversity then discuss two spheres of public health influence. First, we discuss the role (and duty) of those working in public health to lobby for measures to tackle climate change and other threats to biodiversity. The second sphere of influence exploits the local links between access to biodiverse environments and public health, and the chapter examines how people (especially urban dwellers) can be encouraged to engage with such environments. This includes a critical look at the evidence for interventions that bring humans into health-promoting biodiverse environments, and we summarise the literature in a model. We explicate how a range of nature-based activities (including 'green care') within the nature, health and wellbeing sector can be used as environmentally biodiverse interventions to promote well-being, and we include two case studies on how organisations can enable communities to access and sustain biodiverse environments for the benefit of human and planetary health. Finally, we evaluate how access to biodiverse greenspace can fulfil the public health objective of reducing inequalities in health that are linked to socioeconomic status. 


\subsection{Overview of Associations Between Public Health and Biodiversity}

Some ecosystem benefits in Fig. 11.1 rely on explicit exploitation of biodiversity (e.g. for food, medicine). There is abundant evidence that biodiversity is required for the basic needs of life (e.g. food, clean water). However, for 'nature experience', biodiversity could have an impact on human health via multiple pathways, and these could operate differently depending on whether the nature experience is 'passive' or 'active'. A more biodiverse environment may offer greater opportunities for active participation, whereby the pathways to health outcomes could include physical activity and a reduction in social isolation. There are a number of theories proposed by which passive exposure to nature improves well-being, including Wilson's (1984) Biophilia hypothesis, Ulrich et al.'s (1991) Stress Recovery Theory, and Kaplan and Kaplan's (1989) Attention Restoration Theory (see Marselle Chap. 7, this volume, for further discussion of these theories). Specifically, greater biodiversity may offer greater scope for 'soft fascination' (passive interaction, entered into almost involuntarily, catching and holding one's attention), a feature of Attention Restoration Theory. Greater biodiversity would also be more likely to trigger the innate response predicted by the Biophilia Hypothesis.

A given habitat can simultaneously provide multiple ecosystem (and therefore health) benefits. For example, tree canopies and open water provide shade and cooling in urban areas, providing physical benefits to human physiological systems, and can elicit aesthetic and spiritual benefits, thereby reducing stress, mental fatigue and exhaustion. Exposure to greenspace has been linked to a range of health benefits (Maas et al. 2006; Nieuwenhuijsen et al. 2017), and more naturalistic (and therefore possibly more biodiverse) environments have been postulated as being best suited to promoting such benefits (e.g. Tyrvainen et al. 2014). There is little empirical evidence that biodiversity specifically (rather than natural environments in general) contributes directly to human health and well-being. Lovell et al.'s (2014) systematic review identified only 17 studies that included an explicit consideration of biodiversity and a health outcome, ten of which suggested an association. In the wider literature, there is some expectation that habitats found to provide health and well-being benefits may also be biodiverse; for example, Park et al. (2011) reported mood changes, including in depression, when comparing forest to urban settings. One major work that does explicitly link human health with biodiversity in an urban context is Fuller et al. (2007), who found an increase in psychological well-being with exposure to sites of high biodiversity (species richness). Luck et al. (2011) also described associations between well-being and biodiversity (especially of vegetation). Much other research in this area provides evidence of (mainly positive) links between people's perception of biodiversity and health and well-being benefits. From the wider literature, we can postulate some specific components of biodiversity that link to aspects of public health. Figure 11.2 presents a summary of our review of the links between levels of biodiversity (rows) and domains of public health (columns). The body of the table gives our assessment of the state of the evidence for links between the domains and levels of biodiversity. In general, the evidence for a direct link between biodiversity 


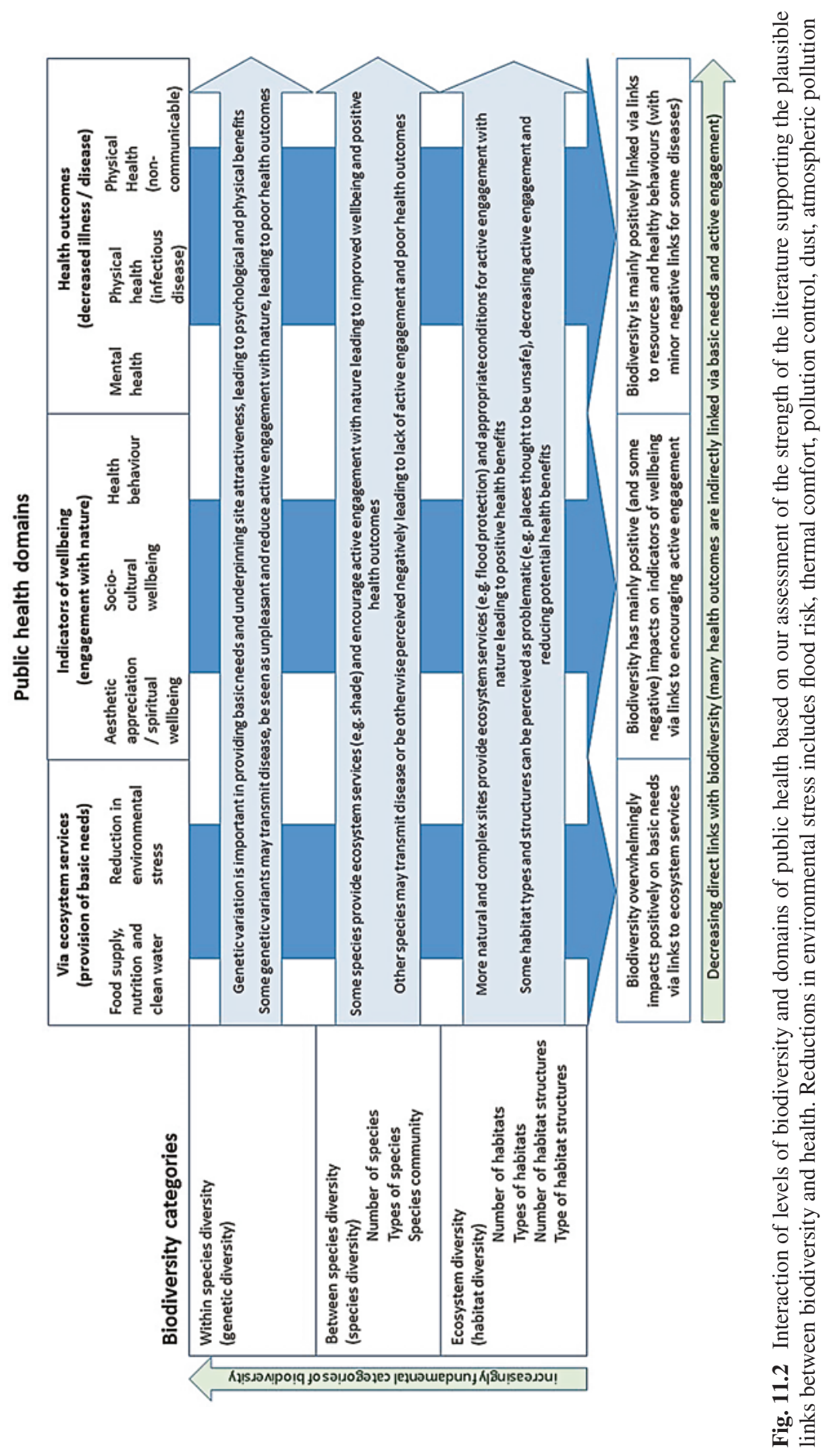


and health outcomes (the column on the right of Fig. 11.2) is less clear since the evidence of a causal relationship is less well established. However, there are plausible indirect links via the provision of the basic needs of life, which links to well-being and mental and physical health outcomes. There are also plausible (but unproven) direct relationships between exposure to biodiversity and mental and physical health outcomes. The following subheadings take each public health domain in turn and provide some selected examples to illustrate a public health viewpoint. A comprehensive review is beyond the scope of this chapter.

\subsubsection{Food, Nutrition and Clean Water Supply}

Biodiversity at all levels is linked to access to clean water and food of good nutritional value, which are fundamental for healthy populations. Urbanisation increases the distances that food travels and increases the challenges of maintaining clean water supplies. Public and environmental health initiatives are important in mitigating such problems. Increasing urbanisation has been followed by agricultural intensification to supply growing populations, which often leads to a reduction in biodiversity (e.g. Fahrig et al. 2015). However, conserving and enhancing the biodiversity of agricultural areas need not reduce crop productivity; for example, enhanced biodiversity reduces pest infestation, thus reducing the necessity for the use of pesticides (Petit et al. 2015). In addition, providing food across different environmental conditions (including those resulting from climate change) means that maintaining genetic and species diversity may be important in the development of food crops for the future (e.g. Bernstein 2014). There is a growing movement of urban-based food production and the biodiversity of such systems is often greater than those of other areas of greenspace (Lin et al. 2015). The supply of clean water for many cities worldwide relies on (often highly biodiverse) forest environments within the watershed (Dudley and Stolton 2003), although some land uses (including for livestock) may increase the likelihood of microbial contamination of water supplies, for example, with Giardia lamblia and Cryptosporidium species (Schreiber et al. 2015).

\subsubsection{Environmental Stress}

Urban environments tend to have poorer air and water quality, increased noise, decreased thermal comfort and increased stress (World Health Organisation 2016; Wheater 1999). Extreme temperatures in cities via the 'urban heat island' effect is a substantial threat to public health (World Health Organisation 2016). The most vulnerable in society (i.e. with the lowest SES) suffer disproportionately from these stresses (Diaz et al. 2006). Biodiversity can provide ecosystem services that buffer communities from environmental stress (Haines-Young and Potschin 2010), which may become especially important in the context of climate change. For example, 
different species and varieties of trees differ in the extent to which they provide shade, reduce particulate and other pollution, and buffer noise, humidity and temperature, as well as disrupting gusty wind flow through city streets (Wheater 1999). Therefore, a diverse tree community fulfils more of these functions. Higher habitat diversity provides even greater benefits on city cooling than does the presence of greenspace alone (Kong et al. 2014). Flood risk is increasingly important, causing disruption, risk of death from drowning and physical injury, as well as increasing the incidence of diseases (de Man et al. 2014). Biodiverse environments within the watersheds surrounding an urban area can help moderate flood risk (Carter et al. 2017). See Lindley et al. Chap. 2, this volume, for further discussion on the effects of climate change on health, and the use of biodiversity for climate change mitigation.

\subsubsection{Aesthetic Appreciation and Spiritual Well-being}

People have a range of preferences for different observable diversity at the genetic, species, communities of species and habitat levels. Whether viewing nature, experiencing it, or actively engaging with it, certain plants and animals and types of habitats may elicit appreciation or disgust, engagement or rejection. For example, many people feed squirrels in the park but not rats in the back streets (species preferences); others will take walks through open parkland but not dense scrub (habitat preferences). Such preferences may be age- and culture-specific (Bjerke et al. 2006). It is not only the type of species that may be attractive; the number (richness) of species and type of species community also affect aesthetic appreciation. Large populations and communities of birds, wildflowers and trees tend to be perceived as more attractive than swarms of insects or other invertebrates (e.g. Shwartz et al. 2014). Colourful wildflower meadows are usually preferred over sparsely vegetated brownfield sites (even where these contain many of the same species). Southon et al. (2017) identified that more biodiverse meadows increased people's appreciation of sites, and Sang et al. (2016) found that higher perceived naturalness was linked to higher aesthetic appreciation and more active engagement with urban greenspace. In urban greenspace, the presence of scrub may be off-putting if it is perceived as providing cover for criminal activity (Hough 2014).

Some studies have sought to investigate whether well-being is related to conscious perception of biodiversity. People's perception of the level of biodiversity often does not equate to actual biodiversity values. For example, although Southon et al. (2018) did find an alignment between perceived and actual biodiversity for some habitats, Dallimer et al. (2012) suggested that people may not be good at assessing actual biodiversity despite finding a link between perceived species biodiversity and well-being. Lindberg (2012) established that people will distinguish between spaces of differing quality but do not necessarily align these with actual biodiversity. Shwartz et al. (2014) found that people underestimated biodiversity in manipulated plots and were biased towards the biodiversity of particular groups (plants) over others (birds, trees and especially insects). Marselle et al. (2016) found a link between perceived bird biodiversity (but not perceived butterfly or plant/tree 
biodiversity) and restorativeness. The constructs of human health, human wellbeing and biodiversity are multi-dimensional and can be difficult to define and quantify (Naeem et al. 2016).

There appear to be strong links between the aesthetic and spiritual appreciation of nature, with mental health benefits and engagement with outdoor activities. These provide public health professionals with further opportunities to provide advice and interventions for improving the health of vulnerable communities. Interestingly, De Lacy and Shackleton (2017) reported that greenspace associated with urban sacred sites enhanced the spiritual experience of visitors. Nature is deeply embedded into a number of religions, therefore spending time in nature enhances a sense of belonging and the spiritual experience (Lindgren et al. 2018). See Irvine et al. Chap. 10, this volume, for a more indepth discussion about biodiversity and spiritual well-being.

\subsubsection{Socio-cultural Well-being}

Social isolation is linked to increased risk of overall mortality (Holt-Lunstad et al. 2015) and diseases such as coronary heart disease and stroke (Valtorta et al. 2016). Promoting social interaction is a key public health priority; one that could be facilitated by access to natural environments (World Health Organisation 2016). The Social Finance Report conveys the positive impact of biodiverse environments on older people and suggests that physical activity in the outdoor environment reduces social isolation, which in turn can reduce GP attendance and A\&E admissions (Social Finance 2015). Access to nature and nature-based approaches such as green care can have a positive influence on an individual's social activation (Gonzalez et al. 2009). However, there are differences in how urban greenspace is used by different ages, genders and cultures (e.g. Bjerke et al. 2006; Maas et al. 2008), which may influence how planning takes place for public health purposes (e.g. Sang et al. 2016). See Kabisch Chap. 5, this volume, for more about the role of sociodemographic factors in greenspace and health effects.

\subsubsection{Health Behaviour Including the Promotion of Physical Activity}

Creating opportunities for engaging with physical activity and other healthy behaviours is important in public health practice. Research demonstrates that a sedentary lifestyle contributes to increases in coronary heart disease, diabetes and obesity (Wilmot et al. 2012). Studies have shown that people living nearer to parks were more likely to use them for physical activity (World Health Organization 2016) and were less likely to be overweight or obese (Coombes et al. 2010). Levels of physical activity were higher in greener neighbourhoods and, in those with over $15 \%$ greenspace, cardiovascular disease risk was reduced (Richardson et al. 2013). However, the biodiversity of habitats preferred for physical activity may vary with the activity 
involved, and the age group of the participants (e.g. Ward Thompson 2013). For example, playing (informal) football requires a large amount of open space with significant buffer zones separating the activity from other uses (Golicnik and Ward Thompson 2010). Such space would not tend to be particularly biodiverse. Runners and cyclists may prefer more open environments, whilst walkers may select more structured habitats. Site management may exploit such preferences to avoid conflicts (and even collisions) on shared tracks (Santos et al. 2016). People report greater enjoyment of outdoor exercise compared to equivalent exercise performed indoors (Thompson Coon et al. 2011). However, Shanahan et al. (2016) identify a knowledge gap in understanding which characteristics of nature are important in promoting physical activity. Exercise also benefits the immune system (Pedersen et al. 2007): general exercise releases myokines, and this effect is greater in colder environments, such as when exercising outdoors in a temperate climate. Myokines induce an inflammatory/pro-inflammatory response control, influencing the function of chronic inflammation, and can positively affect cognition, reduce depression and reduce inflammatory responses associated with osteoporotic disease (Kaji 2016). For a detailed discussion on green space interventions to promote physical activity, see Hunter et al. Chap. 17, this volume.

\subsubsection{Mental Health}

While the direct association between appreciation of different levels of biodiversity and well-being are clear, this is less so for mental health (as measured by the absence of mental disorders such as anxiety or depression). However, there is a clear link between access to natural environments and mental health (World Health Organization 2016). Bragg and Atkins (2016) suggest that three key components (being in the environment, meaningful activities within the environment, and the social context) can positively influence mental health. Both active participation in greenspace and observable greenspace are significant in achieving mental health benefits (Nutsford et al. 2013), and horticultural activities programmes for older people lead to reduced levels of depression and improved life satisfaction (Masuya et al. 2014). There is some evidence that exposure to 'beautiful' nature (potentially equating to perceived biodiversity) promotes socially desirable behaviours (Zhang et al. 2014). Beyer et al. (2014) suggested that greening could be useful within a population mental health strategy. For a more in-depth discussion on mental health and biodiversity, see de Vries and Snep Chap.8, this volume, and Marselle et al. Chap. 9, this volume.

\subsubsection{Physical Health - Infectious Disease (Disease/Pathogen Reduction)}

The links between biodiversity and infectious disease are complex. Although Bernstein (2014) suggested a possible swamping of disease transmission agents by larger species diversity, Wood et al. (2014) identified no such reduction for many diseases, 
suggesting that if such links were important then biodiversity may increase disease. Conversely, Keesing et al. (2010) found that, although areas of high biodiversity can be a source pool for new pathogens, there was increasing evidence that biodiversity loss can increase disease transmission. They suggested that preserving areas with endemic biodiversity should generally reduce infectious disease prevalence.

Sandifer et al. (2015) examined the links between microbial biodiversity, allergic reactions and respiratory diseases, arguing that exposure to microbial diversity can improve health, for example, reducing allergens that may also influence the management of some respiratory conditions. This reinforces aspects of the 'hygiene hypothesis', which proposes that exposure to microbes at an early age can enhance inflammatory responses and thus heighten human resilience to allergens (Hanski et al. 2012). This point was also reported by Ege et al. (2011), who identified that children raised on a farm were less likely to suffer from asthma. See Damialis et al. Chap. 3, this volume, for further discussion on allergenic responses, and Müller et al. Chap. 4, this volume, for more information about vector borne disease.

\subsubsection{Physical Health - Non-Communicable Disease}

Systematic review-level evidence demonstrates that proximity to greenspace is linked to a reduction in mortality due to all causes (van den Berg et al. 2015). Cross-sectional studies show increased neighbourhood greenspace is linked to lower levels of type 2 diabetes (Bodicoat et al. 2014). When specifically considering the role of biodiversity, the effects on physical health outcomes are likely to be indirect, via nutrition, protection from stressors, positive effects on personal and socio-cultural well-being, and creation of desirable natural areas for healthy behaviour. Epidemiological studies have been useful in providing evidence of a link between exposure to greenspace and health outcomes measurable at an area and population level (Mitchell and Popham 2008; de Vries et al. 2003). However, fully making the case for the health benefits of biodiverse environments will require further work on the type and nature of the greenspace and its links to health. Much work at the area level has tended to use crude measures of exposure to biodiversity; for example, the percentage of greenspace in the local environment. Recently, Dennis et al. (2018) have developed a sophisticated landcover model that incorporates socio-demographics for an urban city area. Early findings suggest that the strength of the health-greenspace relationship depends on the nature of the greenspace, with lower diversity greenscapes (recreational grassland) having a less strong relationship with good health compared to areas with more complex greenspace (e.g. shrubs and trees).

Access to greenspace in general has been suggested to be beneficial in the management of long-term conditions such as obesity, cardiovascular disease and diabetes. Moreover, when people exercise in the natural environment, the impact of the two protective factors, exercise and greenspace, acting together may be greater than simply summing the positive effects (i.e. may be synergistic: Shanahan et al. 2016). The protective effect of greenspace begins early in life: among children, those with access to gardens and greenspace were less likely to be obese at age 7 years (Schalkwijk et al. 
2018). For more on the effect of greenspace on children's health, see Dadvand et al. Chap 6, this volume. Chen and Janke (2012) reported that older people who garden suffer from fewer falls, possibly due to improved gait and balance.

\subsection{The Role of Public Health in Lobbying for Protecting Biodiversity}

Human societies increasingly place species and natural habitats (especially biodiverse habitats) under considerable pressure (Lawton et al. 2010). Threats to biodiversity include urbanisation, intensive agriculture, increased pollution and impacts of climate change. Whilst the first three threats can be managed locally, regionally or nationally, climate change requires international cooperation. The role and responsibility of public health experts to campaign on climate change and other threats to biodiversity are given forcefully in the 2015 Lancet Commission on Health and Climate Change (Watts et al. 2015). It has become vital for health departments of governments not to operate in isolation; health professionals need to ensure that climate-health-related considerations are integrated into government-wide strategies. One example of cross-governmental working can be seen in the recent UK Environment Strategy, in which health features as a major section (DEFRA 2018). In addition to averting biodiversity loss (e.g. preventing deforestation), climate-related topics requiring cross-governmental thinking also impact directly on public health (e.g. phasing out coal as an energy source will protect cardiovascular and respiratory health). Initiatives to support lifestyles that are healthy for both humans and the environment will also help to provide resilience in the face of the health risks posed by climate change. See Keune et al. Chap 15, this volume, for further information on international and national nature-health initiatives.

Public health professionals need to ensure investment in health systems that can respond to climate change-induced threats to human health. For example, urban flooding can be a significant risk to human health both directly (through the risk of drowning) and through exposure to pathogenic microbes (Jørgensen et al. 2016). Similarly, changes in extreme temperatures in cities (including in Europe) are contributing to significant increases in heat-related mortality levels (Mitchell et al. 2016). Drought conditions can also exacerbate risks to health, for example, from microorganisms in the plumes from cooling towers (Pagnier et al. 2009), since water drawn from rivers containing municipal waste may become more concentrated during droughts.

The appropriate policy for maintaining and developing greenspaces of appropriate size and accessibility for public health has long been debated. In 1929, for London (UK), Unwin recommended 7 acres (2.83 ha) of greenspace be allocated per 1,000 people as playing fields (first report of the Greater London Regional Planning Committee in 1933, cited by Turner 1992). Later work for English Nature recommended an Accessible Natural Greenspace Standards model with (inter alia) at least 2 ha of natural greenspace within $300 \mathrm{~m}$ of all residents and at least 2 ha of Local Nature Reserve per 1,000 people (Harrison et al. 1995). It was recognised that 
such guidance was not being implemented by all local authorities and Pauleit et al. (2003) recommended the standards become flexible to address local contexts. Whilst greenspace standards may be appropriate to promote human health and wellbeing, these may need to be revised if greenspace is to mitigate the impacts of climate change on urban centres. For additional discussion about how human health is addressed in planning legislation, see Heiland et al. Chap. 20, this volume.

The International Convention on Biodiversity (2017) suggested that there is already sufficient evidence to justify several actions to protect human health, including integrating biodiverse greenspaces in urban development. It identified the need to address the drivers of ill health and biodiversity loss together (for further discussion on policies linking biodiversity, health and climate change, see Korn et al. Chap. 14, this volume). Governments should invest in research and monitoring, including quantifying the savings from reduced health-care costs and the enhanced productivity that would accompany climate change mitigation (Convention on Biodiversity 2017; Watts et al. 2015). Internationally, governments must support countries to become low carbon economies as a global endeavour (Watts et al. 2015), since consumption in wealthier countries drives carbon use in less wealthy countries. Public health professionals need to engage the public as well (Corner et al. 2014): framing climate change concerns around health and well-being may be more powerful than arguing to conserve the environment without an explicit link to human health (Myers et al. 2012).

\subsection{Public Health Action at a Local Level}

Locally, a public health-informed system would encourage cities to support lifestyles that benefit both humans and the environment. Steps to achieve this include the development of highly energy-efficient sustainable housing; available low-cost active transportation; and increased access to greenspaces. These measures would promote more resilience in human health, whilst also reducing urban pollution, greenhouse gas emissions, rates of diseases associated with poor air quality (Watts et al. 2015) and diseases associated with a sedentary lifestyle (e.g. cardiovascular disease, cancer, obesity, diabetes). Whilst we acknowledge that all such actions are vital to the public health professional's role, here we focus on access to biodiverse greenspaces.

Although cities are places where the benefits of nature have been historically disregarded in favour of clean and hygienic space (Keune et al. 2013), the concept of greenspace as a resource for public health is long-standing. Access to, and immersion with, nature was first championed in 1772 by the English politician, Joseph Addison and later by the founder of nursing, Florence Nightingale (1860). Many Victorian public parks were created as a public health resource (Wheater et al. 2007). Historically, the visual experiences of rural landscapes as a source of refreshment and renewal of physical, mental and spiritual health was thought to complement medical approaches, and this belief influenced the location of asylums in the 19th century (Hickman 2009). The tradition of therapeutic landscapes was suggested in 1992 by Wilbert Gesler (Bell et al. 2018), who described these as natural 
environments, which interact with the social environment, to provide spaces of healing.

A complex set of transactions between accessing greenspace and participating in greenspace led Bell et al. (2018) to develop "palettes of place" from macro-scale areas (countryside, coasts and seaside), through meso-scale (urban parks and riversides) to micro-scale palettes (hospitals, clinic gardens, woods and allotments). Pauleit et al. (2003) make the point that greenspace needs not only to be accessible, but also of good quality. Quality influences the way nature is perceived, and the extent to which people participate in and use nature (Kaplan and Kaplan 1989; Pretty et al. 2005). The modern shift to engage nature has emerged from an ambition to use biodiversity to nurture human health. Hence, the appetite to determine the effect of a mere view of nature has evoked research in a range of settings, populations and activities to illustrate the therapeutic influence of the landscape. For example, Ulrich's (1984) seminal work exploring the restorative influence of views from windows on post-operative recovery of patients following cholecystectomy was one of the first influential studies to demonstrate the positive effects a view of nature can have on recovery. Ulrich reported that patients with a view of trees spent less time in hospital and required less analgesic than those without such views. It is worth noting that behaviour and cognition may also be moderated by naturalistic views: Kuo and Sullivan (2001) recorded reduced aggression associated with mental fatigue for residents in greener (naturebased) buildings, and Taylor et al. (2002) identified increased self-discipline (in girls at least) with increased natural views from home.

The ways in which exposure and engagement with nature for well-being has diffused into contemporary public health intervention strategies has been described in a series of models, which we have integrated and reformulated to incorporate the potential for biodiversity enhancement (Fig. 11.3). As a starting point, three distinct ways in which individuals engage with nature are described (Haubenhofer et al. 2010): (i) through outdoor activities such as walking as part of everyday life activities; (ii) through recreational activities such as the use of cycle paths and structured outdoor activities that could promote health; and (iii) nature being used as a therapeutic intervention within a 'green-care' context (left to right in Fig. 11.3). The latter includes, for example, those "nature-based therapy or treatment interventions specifically designed, structured and facilitated for individuals with a defined need" (Bragg and Atkins 2016: 18). Hence the 'nature, health and well-being sector' is a term used to describe green care and health promotion services. The levels of nature and extent to which nature can be used to support well-being is depicted from top to bottom of Fig. 11.3 as earlier described by Pretty et al. (2005), who note that at one level ("viewing nature"), an individual is simply exposed to an environment through vistas; a second level ("being in the presence of nature") involves greater participation in nature through activities such as walking or gardening (referred to as green exercise). The final level ("active participation in nature") is based on a more prescribed approach where activities are considered as "therapies", with an intention to treat, heal or alleviate through experiencing and interacting with nature. Since none of the existing models explicitly consider biodiversity, we have added consideration of how biodiversity links with each of the levels of engagement and how this may be enhanced to improve actual (as well as perceived) biodiversity. The intensity of the 


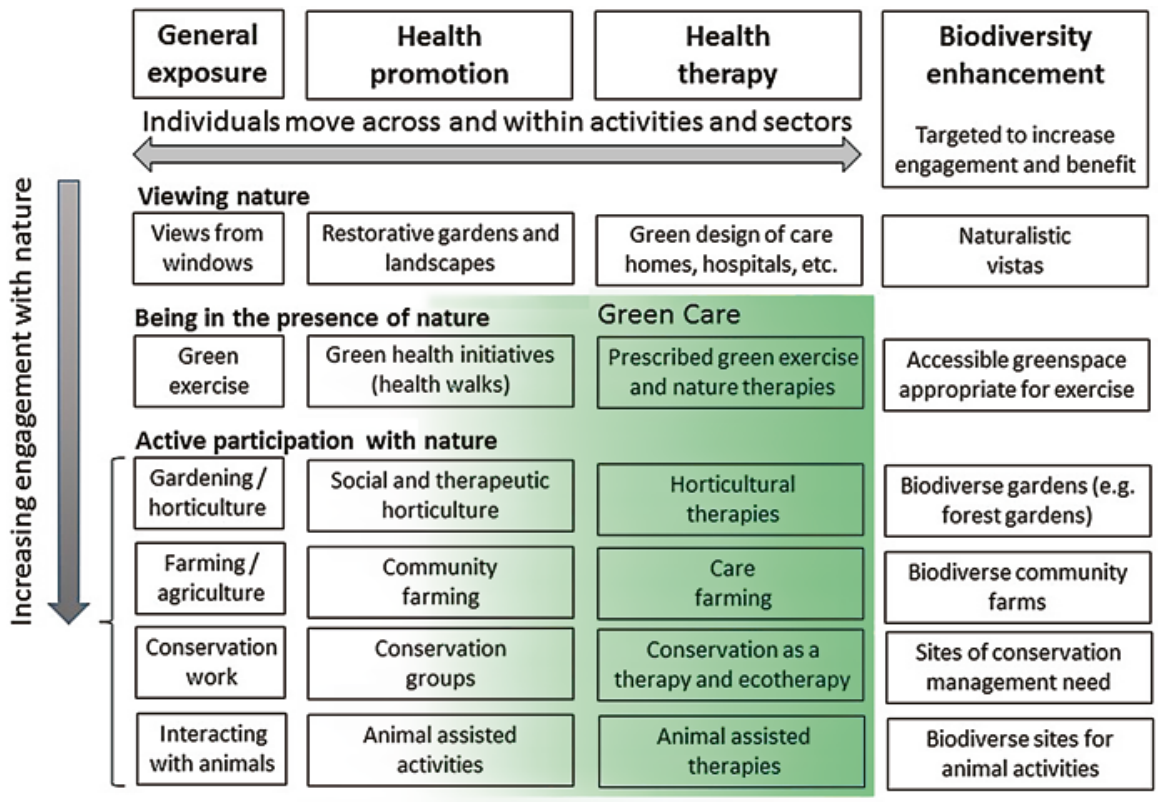

Increasing targeting of public health activities

Fig. 11.3 Model of the interactions between level of engagement with nature, level of public health targeting (combining the models of Pretty et al. 2005; Haubenhofer et al. 2010; Annerstedt and Währborg 2011; Bragg and Leck 2017) with the additions of potential benefits due to enhanced biodiversity. Green care (shaded area) covers a range of targeted activities that overlap those developed through health promotion as well as specific health therapies

exposure to biodiversity varies depending on activity, and is likely to be higher when the participation is more active. For example, conservation volunteering may involve handling plant-life and soil, which brings people intimately in touch with biodiversity (soils can be extremely biodiverse even if they are not always perceived that way). Therapeutic gardens could be biodiverse, for example, through the variety in species required in the creation of a sensory garden. As per the Bragg and Leck (2017) extension to the existing models, well-being and the promotion of health are not static, and individuals often move across and within the nature, health and wellbeing sector (i.e. horizontally between health promotion and health therapy, and diagonally between different activities and therapies).

Box 11.1 is a case study that illustrates the variety of activities that can be supported in a community forest. This suggests multiple beneficial opportunities to access, engage with and, where prescribed, undertake as a therapy. Active participation probably has greater health benefits (Collins and O'Callaghan 2008), and more biodiverse environments can increase the therapeutic effects on humans (Annerstedt and Währborg 2011). Interventions that encourage people to support biodiversity, for example through choice of species when gardening, have the potential to simul- 


\section{Box 11.1: Case Study}

\section{City of Trees}

Jessica Thompson, Health and Well-being Lead, City of Trees, UK

The City of Trees (City of Trees 2018) movement based in Greater Manchester is one of the UK's Community Forestry (England's Community Forests 2018) organisations and forms part of the Northern Forest concept (Braby 2018). City of Trees represents urban forestry, a term widely used in the USA and Northern Europe to define the 'art, science and technology' in relation to trees and plants that exist within an urban setting as well as the "physiological, sociological, economic, and aesthetic benefits trees provide society" (Konijnendijk et al. 2006). In its physical form, the urban forest includes all aspects of green infrastructure found within the urban setting at varying spatial scales, e.g. the mosaic of street trees, woodlands, parks, orchards, gardens, incidental greenspaces, etc. City of Trees advocates a natural capital approach to the benefits of green infrastructure, described as ecosystem services (Natural England 2009), such as biodiversity, climate change adaptation, recreation, health and well-being.

City of Trees strives to be a public facing movement. A team delivers campaigns and community engagement programmes, such as Green Streets (a neighbourhood-greening programme that facilitates community-based street tree planting, Fig. 11.4), community orchard creation and pocket woodland

Fig. 11.4 A

neighbourhood greening programme that facilitates community-based street planting. (Photo credit: City of Trees)

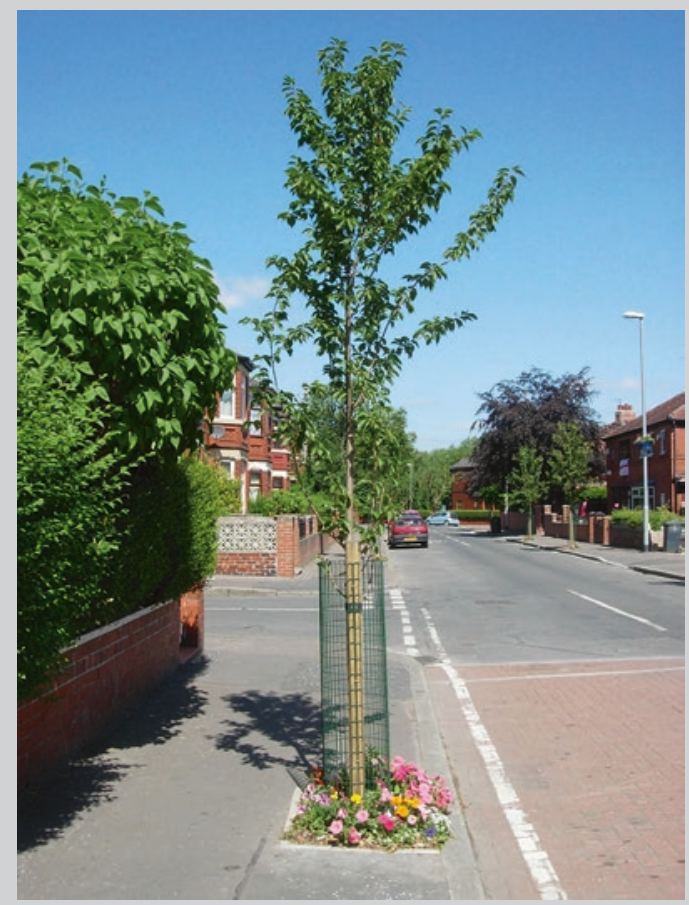




\section{Box 11.1 (continued)}

planting, giving people the power to bring nature, biodiversity and food growing to their neighbourhoods. Outreach initiatives such as Woodland Futures and Dementia Naturally Active aim to connect people to nature (Fig. 11.5) as well as tackle issues around social isolation, by providing nature-based activities for therapeutic and vocational rehabilitation. Green infrastructure gives people the opportunity to become stewards of ecosystem services (Andersson et al. 2014), and City of Trees aims to inspire social inclusion through its volunteer initiative, Citizen Forester, encouraging a wide range of audiences to take part in tree planting, woodland habitat management and citizen science recording of tree species. City of Trees also works strategically to strive for an environmental justice approach to developing high-quality green infrastructure, to encourage utility and recreational walking and cycling in support of healthier lifestyles. The work and outcomes of City of Trees has implications for public health priorities on prevention, self-care and early intervention to improve population health and health inequalities.

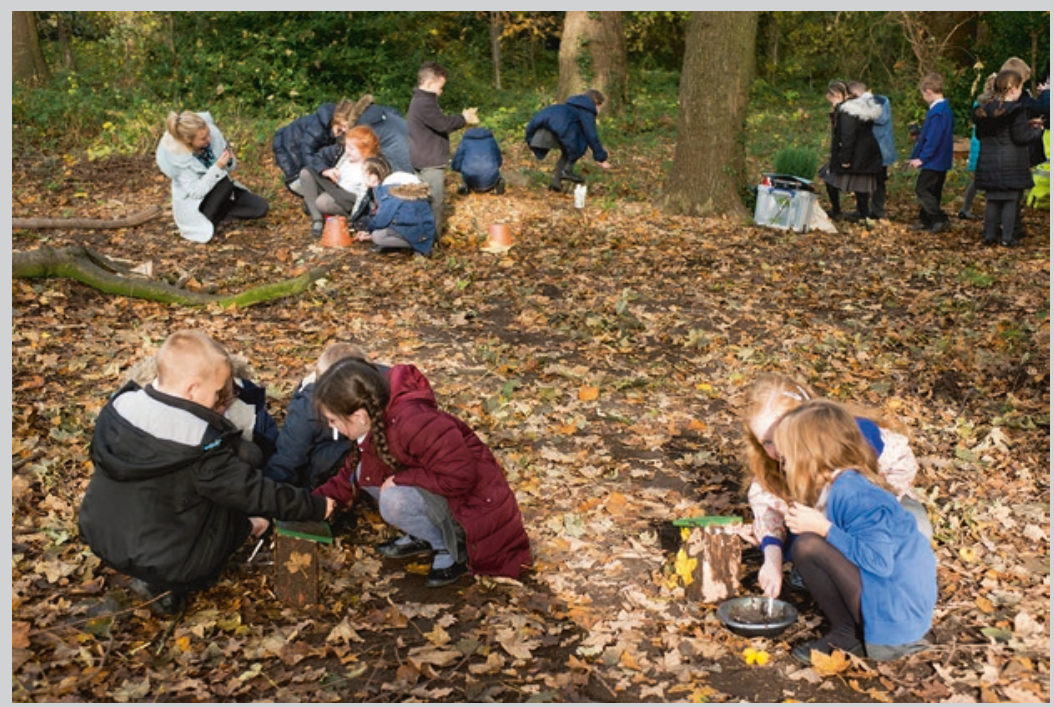

Fig. 11.5 Outreach work with schools connects young people with nature. (Photo credit: City of Trees) 


\section{Box 11.2: Case Study}

\section{Royal Horticultural Society: Plants for Bugs}

Alistair Griffiths, Director of Science and Collections, Royal Horticultural Society, UK

The Royal Horticultural Society (RHS) has identified that the UK's garden plants, gardeners and the 27 million gardens play a significant role in supporting biodiversity. They concluded that the best strategy for gardeners wanting to support pollinating insects in gardens is to plant a mix of flowering plants from different countries and regions. They also suggest that emphasis is given to plants native to the UK and the northern hemisphere (though exotic plants from the southern hemisphere can be used to extend the season). In addition, regardless of plant origin (native or non-native), the more flowers a garden can offer throughout the year, the greater the number of bees, hoverflies and other pollinating insects it will attract and support (Salisbury et al. 2015, 2017).

The RHS translated this research knowledge so as to reconnect people back with nature and encourage more people to put garden plants that attract wildlife into their gardens. An intervention such as this, which encourages people to support biodiversity through choice of species when gardening, has the potential to simultaneously improve both human health (by increasing exposure to biodiverse environments) and the health of the natural environment. The RHS worked with the UK horticultural industry and with the UK Government's National Pollinator Strategy and produced information for gardeners in the form of bulletins on-line (Royal Horticultural Society 2015).

The research findings were also used and disseminated through the RHS networks such as: through the Campaign for School Gardening with 34,000 schools; Britain in Bloom with 300,000 volunteers; and through shows, gardens, and retail, in order to help safeguard nature. The Plants for Bugs work (Fig. 11.6) showcases how scientific research and development, industry, gardeners and government can join together to inspire people to choose and grow garden plants for pollinator and biodiversity benefit. This creates a new ecosystem-service product line, which in turn increases plant sales and the economic bottom line for the horticulture industry, whilst encouraging and supporting biodiversity.

Pollination is a key ecosystem service that substantially contributes to the global food supply and human nutrition (Fig. 11.7). The RHS Pollinator plant lists have been widely adopted by the horticulture industry, and the government's National Pollinator Strategy (England) launched in November 2014 endorses RHS Plants for Pollinators and encourages gardeners to choose plants that provide resources for pollinators. 
Box 11.2 (continued)

Fig. 11.6 Royal

Horticultural Society Entomologist Andrew Salisbury using the Vortis bug sampler on the Plants for Bugs experimental plots at the Royal Horticultural Society Wisley Garden. (Photo credit: Royal Horticultural Society)

Fig. 11.7 Female hoverfly (Volucella zonaria) on field scabious (Knautia arvensis) on the Plants for Bugs experimental plot. (Photo credit: Royal Horticultural Society)
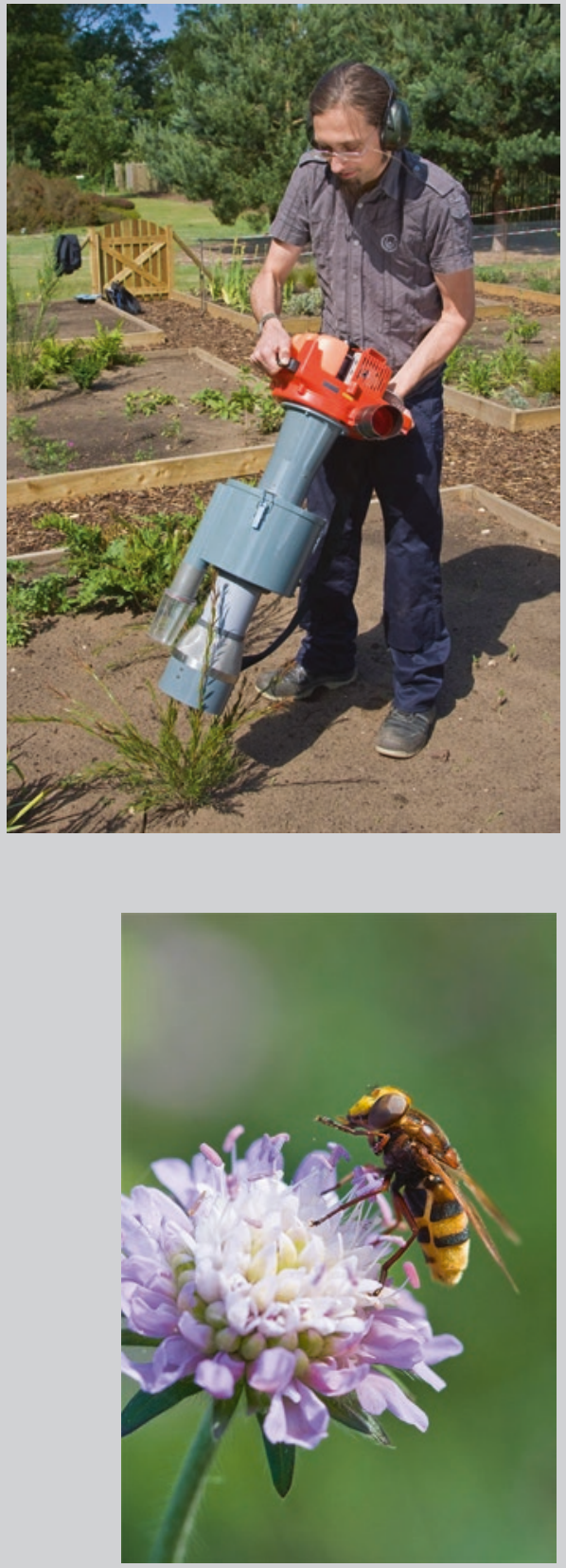
taneously improve both human health and the health of the semi-natural environment (see Box 11.2).

Research over the last 20 years describes a range of nature-based activities that constitute green care and, crucially, the positive impact on health and well-being for people who may be vulnerable or socially excluded (Berget et al. 2012). The increased interest in such innovative approaches to well-being has led to a proliferation of terms used to denote nature-based work; consequently, the terms green care and nature-based interventions are often used interchangeably (Bragg and Atkins 2016). The spectrum of nature-based activities includes gardening, vistas and walking, food growing, community gardens, prescribed (for example, an imposed or recommended regimen) exposure to nature, nature-based activity or structured green care activities (Green Care Coalition 2017). Thus, social prescriptions using outdoor nature-based approaches, as available within the nature, health and wellbeing sectors, provide one way in which health professionals with a public health role might facilitate individuals to access biodiverse greenspace.

\subsubsection{Towards an Emerging Salutogenic Paradigm?}

Salutogensis focuses on factors that support human health and well-being, rather than on those that cause disease (i.e. pathogenesis) (Antonovsky 1979). Predicated on the paradigm that health is a positive state of well-being rather than just "being well" and deterring ill health, salutogenesis originated through Antonovsky's (1979) asset-based approach, which endorses the skills, attributes and resources of individuals and communities to develop resilience and a sense of purpose. Hence, a salutogenic approach has influenced the move away from more medical, pathogenic models to provide a sense of coherence between health and illness.

The lack of proof of causality in the evidence base for biodiversity and human well-being has straitjacketed public health policy. This is because evidence-based commissioning, the process by which health interventions are funded on the basis of their proven effectiveness, requires strong evidence that the intervention (e.g. a green-care intervention) has a causal relationship with health (i.e. disease reduction). This is predicated on a medical evidence hierarchy in which a positivist paradigm prevails. Hence, commissioners may be reluctant to support services lacking experimentally-derived evidence and have been slow to embed salutogenic approaches within health-care policy. However, taking a more proactive and structured approach to the use of nature-based interventions, particularly those involving biodiverse environments, has the potential to influence public health discourse and morph into an emerging salutogenic paradigm. Such interventions may be cost effective by reducing the economic burden on health-care systems; however, in order to demonstrate this, it is essential to develop evaluation methods that can adequately define these health and economic benefits. Evaluation methods need to 
engage with the complexity rather than attempt to reduce it to measurable outcomes, as is recognised by the UK Medical Research Council's guidance on evaluating complex interventions (Craig et al. 2011). Such methods might include natural experiments/quasi-experiments analysed using stepped wedge or interrupted time-series analyses ( $\mathrm{Hu} 2015$ ), and should include a process evaluation to take into account the varying contexts in which the intervention takes place (Moore et al. 2015).

The shift from a medical model has encouraged a rethink of care and care provision and has latterly become established within a 'Social Prescribing' movement. As a non-medical approach, social prescribing interventions promote personcentred and asset-based approaches for people with diverse needs (Polley et al. 2017). Social prescribing can support communities and individuals by placing the "individual or service user in the driving seat so it creates the opportunity for real and lasting behaviour change because it involves learning and making choices" (Jackson 2016: 14). Also referred to as community referral or asset-based, personcentred approaches, there is no agreed single term used to describe social prescribing. Significantly, its definition may be difficult to hone as it is part of a larger social movement, initiated by the UK National Endowment for Science, Technology and the Arts (NESTA), based on 'people-powered health' designed to help reduce health inequalities, as highlighted in the influential UK Marmot Report (2010).

A social prescription enables a health professional to collaborate with a link worker or community navigator who facilitates a person-centred conversation to design the participant's own solutions to well-being (Bertotti et al. 2018). This wellbeing conversation can prevent unnecessary GP attendance, reduce hospital emergency admissions, reduce social isolation, and help support individuals with a range of conditions (Kimberlee et al. 2014; Chatterjee et al. 2017). Approaches to social prescribing range from long-term condition management to volunteer opportunities with a focus on well-being through supported activities (Dayson et al. 2015). Since 2013, four models of social prescribing have emerged: (i) signposting; (ii) linking with specific projects; (iii) joint partnerships; and (iv) holistic referrals (Kimberlee 2013). This includes, but is not exclusive to, therapeutic horticulture- and arts-based approaches. The ways in which these activities occur are diverse and reflect the contemporary public health approach adopted mainly within third-sector organisations, community groups and charities, rather than commissioned health services.

Examples of nature-based social prescribing interventions range from arranged walks in forests to conservation volunteering and more structured 'green-care' activities such as those observed within therapeutic gardens, all of which fit within the frameworks summarised in Fig. 11.3. Since the more active one becomes with nature, the more likely the exposure to biodiversity, health professionals should work with appropriate bodies to maximise biodiversity enhancement of naturebased social prescriptions. The case study in Box 11.2 explicitly brings people into contact with biodiversity for the benefit of the health of participants and the planet. 


\subsection{Use of Biodiverse Natural Environments to Reduce Inequalities in Health}

A major drawback in using greenspace to improve public health is that those who are socially disadvantaged are least likely to have access to good quality greenspace. The health benefits from biodiverse environments tend to be disproportionately experienced by the most advantaged sectors of society (Diaz et al. 2006). This is a social justice issue: the wealthy have less need of the health benefit; they tend to already possess greenspace by having the financial resources to live in greener areas and to own private greenspace; they may travel more extensively to areas of natural beauty; they are more likely to exercise/make use of the greenspace; and finally, they are more likely to displace less advantaged communities from newly greened, previously brownfield sites (i.e. in a process of gentrification).

Estimates of health impacts due to SES can be made at a geographical area level, where for a given area the average SES status is known and health data are available. At such geographical areas (carried out at the neighbourhood level, approximately 1,500 persons), it is also possible to measure aspects of the natural environment using geographical information system databases. These area-level analyses show that greenspace is positively associated with health, even after accounting for SES, e.g. in Holland (de Vries et al. 2003) and the UK (Mitchell and Popham 2008; Dennis et al. 2018). Indeed, the impact of greenspace on health is greater for those in the most deprived neighbourhoods (de Vries et al. 2003; Mitchell and Popham 2008). Specifically, Mitchell and Popham (2008) demonstrated that proximity to greenspace reduced health inequalities, and that this effect was stronger in the neighbourhoods with the lowest SES (Fig. 11.8).

Good access to greenspace in the local environment can disrupt the expected link between relative poverty and ill health (Mitchell et al. 2015). However, Wolch et al. (2014) warn that policies promoting greening of areas for those community areas most in need of such a disruption of health inequality may lead to gentrification and a displacement of the very people most in need. They advocate a balance of greening "just enough" to provide benefits without too great a disruption to planning and development. More research will be needed to determine whether this is appropriate, feasible and at what level it should be implemented.

Residing near to greenspace may not guarantee the full benefits of the natural environment, and in areas where greenspace is more fragmented a more targeted approach might be needed to bring people into contact with nature. This is where the nature, health and well-being sector could target those in socially-deprived neighbourhoods (by using social prescriptions for nature-based interventions) to fit within a public health strategy that aims to reduce inequalities in health. 


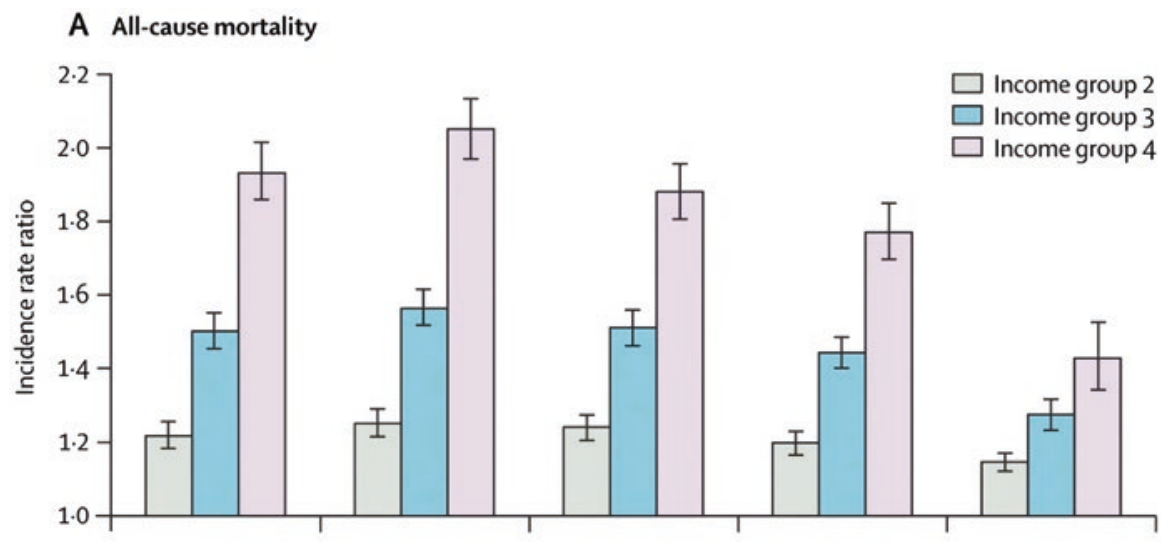

B Deaths from circulatory disease

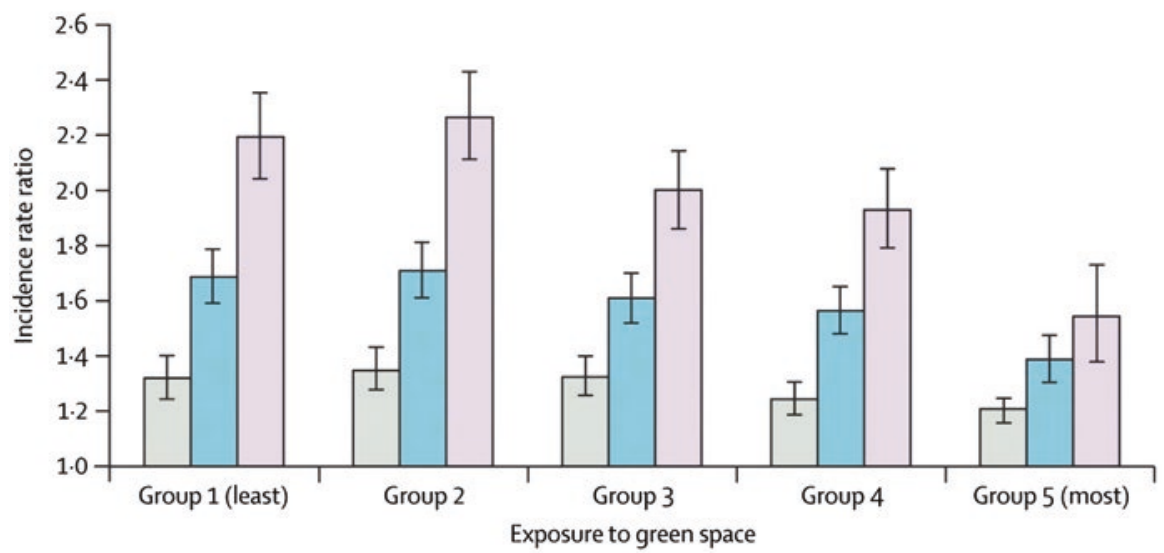

Fig. 11.8 Incidence rate ratios for all-cause mortality (a) and deaths from circulatory disease (b) in income-deprivation quartiles 2-4, relative to income deprivation quartile 1 (least deprived), stratified by exposure to green space. Bars are grouped according to population exposure to green space. Error bars indicate 95\% CIs. The total mortality and deaths from cardiovascular disease decreases with increasing greenspace in the environment. In each category of greenspace, relative to the most wealthy (incidence ratio of 1), there is increasing mortality with decreasing income. However, this disparity is far less apparent in the greenest areas, with the least well off group appearing to benefit the most. (Source: Mitchell and Popham 2008)

\subsection{Conclusion}

Human health is intricately linked with the natural environment. Preservation of the variety of life on the planet is essential to maintain the complex interdependencies between ecosystems and human life. Biodiversity, because of its fundamental relationship with ecosystems services, helps to mitigate the effects of climate change, but is itself at risk of loss due to climate change. Arguably the single biggest priority for public health at a strategic international level is to work across governments and 
countries to protect biodiverse natural resources and introduce measures to stem climate change. Moreover, public support for such an endeavour is likely to be higher if the enormous impact on the health of the human population is emphasised as the outcome of a successful strategy to protect biodiversity and tackle climate change.

Public health professionals need to work on a large scale to support maintenance, enhancement and development of accessible, biodiverse greenspace. Public health leaders should work within governments to ensure that health considerations are incorporated into environment and sustainability strategies, and vice versa. Such strategies should be cognisant of the fact that populations that suffer from poverty and ill health are disproportionately more likely to also suffer from a lack of biodiverse natural environments. While these populations are a priority target for interventions to improve biodiversity, care should be taken that these efforts, by making the environment more pleasant, healthy and desirable, do not cause poorer populations to be displaced.

Public health practitioners are responsible for devising strategies to promote sustainable lifestyles and facilitate access to natural environments. Access to natural environments should be targeted at those most in need. There is an urgent need to embrace the fact that the natural environment is salutogenic, i.e. health giving. There is an equally urgent need to relax the usual positivistic standards of evidence of effectiveness required in medical intervention, and to utilise more suitable methods to evaluate nature-based solutions, for example, using quasi-experimental or mixed methodologies. This will allow more confident investment in schemes that prioritise access to nature over medical intervention. A significant driver for local decision-makers is the anticipated reduction in health-care costs, since improved outcomes will prevent costly use of doctors and hospitals. Such schemes, including nature-based social prescribing, give local commissioners of services the opportunity to target those from socio-economically deprived areas. Those with responsibility for social prescribing should be encouraged to use prescriptions that bring people into contact with nature, preferably where that engagement is active rather than passive. Further, it is likely that interventions resulting in exposure to environments with greater biodiversity will offer the greatest benefits for human health.

Whatever the scale, biodiversity has a fundamental role to play in human health and well-being. Public health professionals need to embrace biodiversity as a resource and be willing to fight to protect it. In so doing, they can target vulnerable populations and reduce inequalities in health between the richest and the poorest in our society.

\section{References}

Acheson D (1988) Public health in England. The report of the Committee of Inquiry into the future development of the public health function. HMSO, London

Acheson D (1998) Inequalities in health - report on inequalities in health did give priority for steps to be tackled. Br Med J 317(7173):1659-1659. https://doi.org/10.1136/bmj.317.7173.1659 
Andermann A (2016) Taking action on the social determinants of health in clinical practice: a framework for health professionals. Can Med Assoc J 188(17-18):E474-E483. https://doi. org/10.1503/cmaj.160177

Andersson E, Barthel S, Borgström S, Colding J, Elmqvist T, Folke C, Gren Å (2014) Reconnecting cities to the biosphere: stewardship of green infrastructure and urban ecosystem services. Ambio 43(4):445-453. https://doi.org/10.1007/s13280-014-0506-y

Annerstedt M, Währborg P (2011) Nature-assisted therapy: systematic review of controlled and observational studies. Scand J Public Health 39(4):371-388. https://doi. org/10.1177/1403494810396400

Antonovsky A (1979) Health, stress, and coping, Jossey-Bass social and behavioral science series. Jossey-Bass, San Francisco

Axelson DJ, Stull MJ, Coates WC (2018) Social determinants of health: a missing link in emergency medicine training. AEM Educ Train 2(1):66-68. https://doi.org/10.1002/aet2.10056

Bell SL, Foley R, Houghton F, Maddrell A, Williams AM (2018) From therapeutic landscapes to healthy spaces, places and practices: a scoping review. Soc Sci Med 196:123-130. https://doi. org/10.1016/j.socscimed.2017.11.035

Berget B, Lidfors L, Palsdottir A, Soini K, Thodberg T (2012) Green care in the Nordic countries - a research field in progress. Report from the Nordic research workshop on green care in Trondheim. Health UMB, Norwegian University of Life Sciences

Bernstein AS (2014) Biological diversity and public health. Annu Rev Public Health 35:153-167. https://doi.org/10.1146/annurev-publhealth-032013-182348

Bertotti M, Frostick C, Hutt P, Sohanpal R, Carnes D (2018) A realist evaluation of social prescribing: an exploration into the context and mechanisms underpinning a pathway linking primary care with the voluntary sector. Prim Health Care Res Dev 19(3):232-245. https://doi. org/10.1017/s1463423617000706

Beyer KMM, Kaltenbach A, Szabo A, Bogar S, Nieto FJ, Malecki KM (2014) Exposure to neighborhood green space and mental health: evidence from the survey of the health of Wisconsin. Int J Environ Res Public Health 11(3):3453-3472. https://doi.org/10.3390/ijerph110303453

Bjerke T, Østdahl T, Thrane C, Strumse E (2006) Vegetation density of urban parks and perceived appropriateness for recreation. Urban For Urban Gree 5(1):35-44. https://doi.org/10.1016/j. ufug.2006.01.006

Bodicoat DH, Donovan G, Dalton AM, Gray LJ, Yates T, Edwardson C, Hill S, Webb DR, Khunti K, Davies MJ, Jones AP (2014) The association between neighbourhood greenspace and type 2 diabetes in a large cross-sectional study. BMJ Open 4(12):e006076

Braby A (2018) A new Northern Forest - beyond the headlines. Woodland Trust https://www. woodlandtrust.org.uk/blog/2018/01/a-new-northern-forest-beyond-the-headlines/, accessed $14 / 02 / 2019$

Bragg R, Atkins G (2016) A review of nature-based interventions for mental health care. London. http://publications.naturalengland.org.uk/publication/4513819616346112

Bragg R, Leck C (2017) Good practice in social prescribing for mental health: the role of naturebased interventions. York

Carter JG, Handley J, Butlin T, Gill S (2017) Adapting cities to climate change - exploring the flood risk management role of green infrastructure landscapes. J Environ Plan Manag:1-18. https://doi.org/10.1080/09640568.2017.1355777

Chatterjee HJ, Camic PM, Lockyer B, Thomson LJM (2017) Non-clinical community interventions: a systematised review of social prescribing schemes. Art Health:1-27. https://doi.org/10 $.1080 / 17533015.2017 .1334002$

Chen TY, Janke MC (2012) Gardening as a potential activity to reduce falls in older adults. J Aging Phys Activ 20(1):15-31. https://doi.org/10.1123/Japa.20.1.15

City of Trees (2018) Growing more trees for Greater Manchester. http://www.cityoftrees.org.uk/. Accessed 26 June 2018

Collins CC, O'Callaghan AM (2008) The impact on health of horticultural responsibility indicators and quality of life in assisted living. HortTechnology 18(4):611-618 
Convention on Biodiversity (2017) Biodiversity and human health. Paper presented at the twentyfirst meeting of the subsidiary body on Scientific, Technical and Technological Advice, Canada, 11-14 December 2017

Coombes E, Jones AP, Hillsdon M (2010) The relationship of physical activity and overweight to objectively measured green space accessibility and use. Soc Sci Med 70(6):816-822. https:// doi.org/10.1016/j.socscimed.2009.11.020

Corner A, Markowitz E, Pidgeon N (2014) Public engagement with climate change: the role of human values. Wiley Interdiscip Rev Clim Chang 5(3):411-422. https://doi.org/10.1002/ wcc. 269

Craig P, Cooper C, Gunnell D, Haw S, Lawson K, Macintyre S, Ogilvie D, Petticrew M, Reeves B, Sutton M, Thompson S (2011) Using natural experiments to evaluate population health interventions: guidance for producers and users of evidence. Medical Research Council. https:// www.mrc.ac.uk/documents/pdf/natural-experiments-guidance/

Dallimer M, Irvine KN, Skinner AMJ, Davies ZG, Rouquette JR, Maltby LL, Warren PH, Armsworth PR, Gaston KJ (2012) Biodiversity and the feel-good factor: understanding associations between self-reported human well-being and species richness. Bioscience 62(1):47-55. https://doi.org/10.1525/bio.2012.62.1.9

Dayson C, Bashir H, Bennett E, Sanderson E (2015) The Rotherham social prescribing service for people with long-term health conditions. Annual evaluation report. Sheffield Hallam University Centre for regional, social and economic research

De Lacy P, Shackleton C (2017) Aesthetic and spiritual ecosystem services provided by urban sacred sites. Sustainability 9(9):Artn 1628. https://doi.org/10.3390/Su9091628

de Man H, van den Berg HHJL, Leenen EJTM, Schijven JF, Schets FM, van der Vliet JC, van Knapen F, de Roda Husman AM (2014) Quantitative assessment of infection risk from exposure to waterborne pathogens in urban floodwater. Water Res 48:90-99. https://doi.org/10.1016/j. watres.2013.09.022

de Vries S, Verheij RA, Groenewegen PP, Spreeuwenberg P (2003) Natural environmentshealthy environments? An exploratory analysis of the relationship between greenspace and health. Environ Plan A 35(10):1717-1731. https://doi.org/10.1068/a35111

DEFRA (2018) A green future: our 25 year plan to improve the environment. OGL, London

Dennis M, Barlow D, Cavan G, Cook P, Gilchrist A, Handley J, James P, Thompson J, Tzoulas K, Wheater P, Lindley S (2018) Mapping urban green infrastructure: a novel landscape-based approach to incorporating land use and land cover in the mapping of human-dominated systems. Land 7(1):17

Diaz S, Fargione J, Chapin FS, Tilman D (2006) Biodiversity loss threatens human well-being. PLoS Biol 4(8):1300-1305. ARTN e277. https://doi.org/10.1371/journal.pbio.0040277

Dudley N, Stolton S (2003) Running Pure: the importance of forest protected areas to drinking water. World Bank/WWF Alliance for Forest Conservation and Sustainable Use

Ege MJ, Mayer M, Normand AC, Genuneit J, Cookson WO, Braun-Fahrlander C, Heederik D, Piarroux R, von Mutius E (2011) Exposure to environmental microorganisms and childhood asthma. N Engl J Med 364(8):701-709. https://doi.org/10.1056/NEJMoa1007302

Elo IT (2009) Social class differentials in health and mortality: patterns and explanations in comparative perspective. Annu Rev Sociol 35:553-572. https://doi.org/10.1146/ annurev-soc-070308-115929

England's Community Forests (2018) About England's community forests. http://www.communityforest.org.uk/aboutenglandsforests.htm. Accessed 18 June 2018

Fahrig L, Girard J, Duro D, Pasher J, Smith A, Javorek S, King D, Lindsay KF, Mitchell S, Tischendorf L (2015) Farmlands with smaller crop fields have higher within-field biodiversity. Agric Ecosyst Environ 200:219-234. https://doi.org/10.1016/j.agee.2014.11.018

Fuller RA, Irvine KN, Devine-Wright P, Warren PH, Gaston KJ (2007) Psychological benefits of greenspace increase with biodiversity. Biol Lett 3(4):390-394. https://doi.org/10.1098/ rsbl.2007.0149 
Golicnik B, Ward Thompson C (2010) Emerging relationships between design and use of urban park spaces. Landsc Urban Plan 94(1):38-53. https://doi.org/10.1016/j.landurbplan.2009.07.016

Gonzalez MT, Hartig T, Patil GG, Martinsen EW, Kirkevold M (2009) Therapeutic horticulture in clinical depression: a prospective study. Res Theory Nurs Pract 23(4):312-328

Green Care Coalition (2017) How does it differ from other nature-based activities? https://greencarecoalition.org.uk/About/How-Does-Green-Care-Differ-From-Other-Nature-BasedActivities/, Accessed 14/02/2019

Haines-Young R, Potschin M (2010) The links between biodiversity, ecosystem services and human well-being. In: Raffaelli DCF (ed) Ecosystem ecology: a new synthesis, BES Ecological Reviews Series. Cambridge University Press, Cambridge

Hanski I, von Hertzen L, Fyhrquist N, Koskinen K, Torppa K, Laatikainen T, Karisola P, Auvinen P, Paulin L, Mäkelä MJ, Vartiainen E, Kosunen TU, Alenius H, Haahtela T (2012) Environmental biodiversity, human microbiota, and allergy are interrelated. Proc Natl Acad Sci 109(21):8334

Harrison C, Burgess J, Allison M, Gerald D (1995) Accessible natural greenspace in towns and cities: a review of appropriate size and distance criteria. No. I53 - English Nature Research Reports, Peterborough

Haubenhofer DK, Elings M, Hassink J, Hine RE (2010) The development of green care in western European countries. Explore 6(2):106-111. https://doi.org/10.1016/j.explore.2009.12.002

Hickman C (2009) Cheerful prospects and tranquil restoration: the visual experience of landscape as part of the therapeutic regime of the British asylum, 1800-60. Hist Psychiatry 20(80 Pt 4):425-441. https://doi.org/10.1177/0957154x08338335

Holt-Lunstad J, Smith TB, Baker M, Harris T, Stephenson D (2015) Loneliness and social isolation as risk factors for mortality: a meta-analytic review. Perspect Psychol Sci 10(2):227-237. https://doi.org/10.1177/1745691614568352

Hough RL (2014) Biodiversity and human health: evidence for causality? Biodivers Conserv 23(2):267-288. https://doi.org/10.1007/s10531-013-0614-1

Hu Y (2015) Stepped wedge, natural experiments and interrupted time series analysis designs. In: Richards DA, Hallberg IR (eds) Complex interventions in health: an overview of research methods. Routledge, Abingdon

Jackson G (2016) Social prescribing at a glance North West England: a scoping report of activity for the North West. Health Education England, Manchester

Jørgensen C, Erichsen A, Mark O, Domingo N, Heinicke G, Hammond M (2016) Dynamic modelling of health risks during wastewater influenced urban flooding. NOVATECH

Kaji H (2016) Effects of myokines on bone. Bonekey Rep 5:Artn 826. https://doi.org/10.1038/ Bonekey.2016.48

Kaplan R, Kaplan S (1989) The experience of nature: a psychological perspective. Cambridge University Press, Cambridge

Keesing F, Belden LK, Daszak P, Dobson A, Harvell CD, Holt RD, Hudson P, Jolles A, Jones KE, Mitchell CE, Myers SS, Bogich T, Ostfeld RS (2010) Impacts of biodiversity on the emergence and transmission of infectious diseases. Nature 468(7324):647-652. https://doi.org/10.1038/ nature 09575

Keune H, Martens P, Kretsch C, Prieur-Richard A-h (2013) Chapter 16 - the natural relation between biodiversity and public health: an ecosystem services perspective. In: Ecosystem services. Elsevier, Boston, pp 181-189. https://doi.org/10.1016/B978-0-12-419964-4.00016-0

Kimberlee R (2013) Developing a social prescribing approach for Bristol. Project Report. University of the West of England, Bristol. http://eprints.uwe.ac.uk/23221/1/Social\%20 Prescribing\%20Report-final.pdf

Kimberlee R, Ward R, Jones M, Powell J (2014) Measuring the economic impact of Wellspring Healthy Living Centre's Social Prescribing Wellbeing Programme for low level mental health issues encountered by GP services. University West of England

Kong FH, Yin HW, James P, Hutyra LR, He HS (2014) Effects of spatial pattern of greenspace on urban cooling in a large metropolitan area of eastern China. Landsc Urban Plan 128:35-47. https://doi.org/10.1016/j.landurbplan.2014.04.018 
Konijnendijk CC, Ricard RM, Kenney A, Randrup TB (2006) Defining urban forestry - a comparative perspective of North America and Europe. Urban For Urban Gree 4(3):93-103. https:// doi.org/10.1016/j.ufug.2005.11.003

Kuo FE, Sullivan WC (2001) Aggression and violence in the Inner City: effects of environment via mental fatigue. Environ Behav 33(4):543-571. https://doi.org/10.1177/00139160121973124

Lawton JH, Brotherton PNM, Brown VK, Elphick C, Fitter AH, Forshaw J, Haddow RW, Hilborner S, Leafe RN, Mace GM, Southgate MP, Sutherland WJ, Tew TE, Varley J, Wynne GR (2010) Making space for nature: a review of England's wildlife sites and ecological network. London

Lin BB, Philpott SM, Jha S (2015) The future of urban agriculture and biodiversity-ecosystem services: challenges and next steps. Basic Appl Ecol 16(3):189-201. https://doi.org/10.1016/j. baae.2015.01.005

Lindberg S (2012) Is biodiversity attractive? On-site perception of recreational and biodiversity values in urban green space. Swedish University of Agricultural Sciences

Lindgren E, Almqvist MS, Elmqvist T (2018) Ecosystem services and health benefits an urban perspective. In: van den Bosch M, Bird W (eds) Oxford textbook of nature and public health: the role of nature in improving the health of a population. Oxford University Press, Oxford

Lovell R, Wheeler BW, Higgins SL, Irvine KN, Depledge MH (2014) A systematic review of the health and Well-being benefits of biodiverse environments. J Toxicol Environ Health Part B 17(1):1-20. https://doi.org/10.1080/10937404.2013.856361

Luck GW, Davidson P, Boxall D, Smallbone L (2011) Relations between urban bird and plant communities and human Well-being and connection to nature. Conserv Biol 25(4):816-826. https://doi.org/10.1111/j.1523-1739.2011.01685.x

Maas J, Verheij RA, Groenewegen PP, de Vries S, Spreeuwenberg P (2006) Green space, urbanity, and health: how strong is the relation? J Epidemiol Community Health 60(7):587-592. https:// doi.org/10.1136/jech.2005.043125

Maas J, Verheij RA, Spreeuwenberg P, Groenewegen PP (2008) Physical activity as a possible mechanism behind the relationship between green space and health: a multilevel analysis. BMC Public Health 8. Artn 206 https://doi.org/10.1186/1471-2458-8-206

Marmot M (2010) Fair society healthy lives. UCL Institute of Health Equity. http://www.instituteofhealthequity.org/projects/fair-society-healthy-lives-the-marmot-review

Marmot M (2013) Review of social determinants and the health divide in the WHO European Region: final report. World Health Organisation, Copenhagen

Marmot M, Wilkinson RG (2005) Social determinants of health, 2nd edn. Oxford University Press, Oxford

Marmot M, Friel S, Bell R, Houweling TAJ, Taylor S (2008) Closing the gap in a generation: health equity through action on the social determinants of health. Lancet 372(9650):16611669. https://doi.org/10.1016/S0140-6736(08)61690-6

Marselle MR, Irvine KN, Lorenzo-Arribas A, Warber SL (2016) Does perceived restorativeness mediate the effects of perceived biodiversity and perceived naturalness on emotional well-being following group walks in nature? J Environ Psychol 46:217-232. https://doi.org/10.1016/j. jenvp.2016.04.008

Masuya J, Ota K, Mashida Y (2014) The effect of a horticultural activities program on the psychologic, physical, and cognitive function and quality of life of elderly people living in nursing homes. Int J Nurs Clin Pract 1:109. https://doi.org/10.15344/2394-4978/2014/109

Mitchell R, Popham F (2008) Effect of exposure to natural environment on health inequalities: an observational population study. Lancet 372(9650):1655-1660. https://doi.org/10.1016/ S0140-6736(08)61689-X

Mitchell RJ, Richardson EA, Shortt NK, Pearce JR (2015) Neighborhood environments and socioeconomic inequalities in mental well-being. Am J Prev Med 49(1):80-84. https://doi. org/10.1016/j.amepre.2015.01.017

Mitchell D, Heaviside C, Vardoulakis S, Huntingford C, Masato G, Guillod BP, Frumhoff P, Bowery A, Wallom D, Allen M (2016) Attributing human mortality during extreme heat 
waves to anthropogenic climate change. Environ Res Lett 11(7):Artn 074006. https://doi. org/10.1088/1748-9326/11/7/074006

Moore GF, Audrey S, Barker M, Bond L, Bonell C, Hardeman W, Moore L, O'Cathain A, Tinati T, Wight D, Baird J (2015) Process evaluation of complex interventions: Medical Research Council guidance. BMJ 350:ARTN h1258. https://doi.org/10.1136/bmj.h1258

Myers TA, Nisbet MC, Maibach EW, Leiserowitz AA (2012) A public health frame arouses hopeful emotions about climate change. Clim Chang 113(3):1105-1112. https://doi.org/10.1007/ s10584-012-0513-6

Naeem S, Chazdon R, Duffy JE, Prager C, Worm B (2016) Biodiversity and human well-being: an essential link for sustainable development. Proc R Soc B 283(1844):Artn 20162091. https:// doi.org/10.1098/Rspb.2016.2091

Natural England (2009) Natural England's green infrastructure guidance (NE176). Natural England, Peterborough. http://publications.naturalengland.org.uk/publication/35033

Nieuwenhuijsen MJ, Khreis H, Triguero-Mas M, Gascon M, Dadvand P (2017) Fifty shades of green pathway to healthy urban living. Epidemiology 28(1):63-71. https://doi.org/10.1097/ Ede. 0000000000000549

Nightingale F (1860) Notes on nursing: what it is, and what it is not. D. Appleton and Co, New York

Nutsford D, Pearson AL, Kingham S (2013) An ecological study investigating the association between access to urban green space and mental health. Public Health 127(11):1005-1011. https://doi.org/10.1016/j.puhe.2013.08.016

Pagnier I, Merchat M, La Scola B (2009) Potentially pathogenic amoeba-associated microorganisms in cooling towers and their control. Future Microbiol 4(5):615-629. https://doi. org/10.2217/Fmb.09.25

Park BJ, Furuya K, Kasetani T, Takayama N, Kagawa T, Miyazaki Y (2011) Relationship between psychological responses and physical environments in forest settings. Landsc Urban Plan 102(1):24-32. https://doi.org/10.1016/j.landurbplan.2011.03.005

Pauleit S, Slinn P, Handley J, Lindley S (2003) Promoting the natural greenstructure of towns and cities: English nature's "accessible natural greenspace standards" model. Built Environ 29(2): 157-170.

Pedersen BK, Åkerström TCA, Nielsen AR, Fischer CP (2007) Role of myokines in exercise and metabolism. J Appl Physiol 103(3):1093-1098. https://doi.org/10.1152/ japplphysiol.00080.2007

Petit S, Munier-Jolain N, Bretagnolle V, Bockstaller C, Gaba S, Cordeau S, Lechenet M, Meziere D, Colbach N (2015) Ecological intensification through pesticide reduction: weed control, weed biodiversity and sustainability in arable farming. Environ Manag 56(5):1078-1090. https://doi.org/10.1007/s00267-015-0554-5

Polley M, Bertotti M, Kimberlee R, Pilkington K, Refsum C (2017) A review of the evidence assessing impact of social prescribing on healthcare demand and cost implications. University of Westminster

Pretty J, Peacock J, Sellens M, Griffin M (2005) The mental and physical health outcomes of green exercise. Int J Environ Health Res 15(5):319-337. https://doi.org/10.1080/09603120500155963

Richardson EA, Pearce J, Mitchell R, Kingham S (2013) Role of physical activity in the relationship between urban green space and health. Public Health 127(4):318-324. https://doi. org/10.1016/j.puhe.2013.01.004

Royal Horticultural Society (2015) Plants for Bugs results. https://www.rhs.org.uk/science/ conservation-biodiversity/plants-for-bugs/plants-for-bugs-results, Accessed 14/02/2019

Salisbury A, Armitage J, Bostock H, Perry J, Tatchell M, Thompson K (2015) Enhancing gardens as habitats for flower-visiting aerial insects (pollinators): should we plant native or exotic species. J Appl Ecol 52(5):1156-1164. https://doi.org/10.1111/1365-2664.12499

Salisbury A, Al-Beidh S, Armitage J, Bird S, Bostock H, Platoni A, Tatchell M, Thompson K, Perry J (2017) Enhancing gardens as habitats for plant-associated invertebrates: should we plant native or exotic species? Biodivers Conserv 26(11):2657-2673. https://doi.org/10.1007/ s10531-017-1377-x 
Sandifer PA, Sutton-Grier AE, Ward BP (2015) Exploring connections among nature, biodiversity, ecosystem services, and human health and well-being: opportunities to enhance health and biodiversity conservation. Ecosyst Serv 12:1-15. https://doi.org/10.1016/j.ecoser.2014.12.007

Sang AO, Knez I, Gunnarsson B, Hedblom M (2016) The effects of naturalness, gender, and age on how urban green space is perceived and used. Urban For Urban Gree 18:268-276. https:// doi.org/10.1016/j.ufug.2016.06.008

Santos T, Mendes RN, Vasco A (2016) Recreational activities in urban parks: spatial interactions among users. J Outdoor Recreat Tour 15:1-9. https://doi.org/10.1016/j.jort.2016.06.001

Schalkwijk AAH, van der Zwaard BC, Nijpels G, Elders PJM, Platt L (2018) The impact of greenspace and condition of the neighbourhood on child overweight. Eur J Pub Health 28(1):88-94. https://doi.org/10.1093/eurpub/ckx037

Schreiber C, Rechenburg A, Rind E, Kistemann T (2015) The impact of land use on microbial surface water pollution. Int J Hyg Environ Health 218(2):181-187. https://doi.org/10.1016/j. ijheh.2014.09.006

Shanahan DF, Franco L, Lin BB, Gaston KJ, Fuller RA (2016) The benefits of natural environments for physical activity. Sports Med 46(7):989-995. https://doi.org/10.1007/s40279-016-0502-4

Shwartz A, Turbe A, Simon L, Julliard R (2014) Enhancing urban biodiversity and its influence on city-dwellers: an experiment. Biol Conserv 171:82-90. https://doi.org/10.1016/j. biocon.2014.01.009

Social Finance (2015) Investigating to Tackle Loneliness; A Discussion Paper. London. https:// www.socialfinance.org.uk/sites/default/files/publications/investing_to_tackle_loneliness.pdf

Southon GE, Jorgensen A, Dunnett N, Hoyle H, Evans KL (2017) Biodiverse perennial meadows have aesthetic value and increase residents' perceptions of site quality in urban green-space. Landsc Urban Plan 158:105-118. https://doi.org/10.1016/j.landurbplan.2016.08.003

Southon GE, Jorgensen A, Dunnett N, Hoyle H, Evans KL (2018) Perceived species-richness in urban green spaces: cues, accuracy and Well-being impacts. Landsc Urban Plan 172:1-10. https://doi.org/10.1016/j.landurbplan.2017.12.002

Stringhini S, Carmeli C, Jokela M, Avendaño M, Muennig P, Guida F, Ricceri F, d'Errico A, Barros H, Bochud M, Chadeau-Hyam M, Clavel-Chapelon F, Costa G, Delpierre C, Fraga S, Goldberg M, Giles GG, Krogh V, Kelly-Irving M, Layte R, Lasserre AM, Marmot MG, Preisig M, Shipley MJ, Vollenweider P, Zins M, Kawachi I, Steptoe A, Mackenbach JP, Vineis P, Kivimäki M (2017) Socioeconomic status and the $25 \times 25$ risk factors as determinants of premature mortality: a multicohort study and meta-analysis of 1.7 million men and women. Lancet 389(10075):1229-1237. https://doi.org/10.1016/S0140-6736(16)32380-7

Taylor AF, Kuo FE, Sullivan WC (2002) Views of nature and self-discipline: evidence from inner city children. J Environ Psychol 22(1):49-63. https://doi.org/10.1006/jevp.2001.0241

Thompson Coon J, Boddy K, Stein K, Whear R, Barton J, Depledge MH (2011) Does participating in physical activity in outdoor natural environments have a greater effect on physical and mental wellbeing than physical activity indoors? A systematic review. Environ Sci Technol 45(5):1761-1772. https://doi.org/10.1021/es102947t

Turner T (1992) Open space planning in London: from standards per 1000 to green strategy. Town Plan Rev 63(4):365-386

Tyrvainen L, Ojala A, Korpela K, Lanki T, Tsunetsugu Y, Kagawa T (2014) The influence of urban green environments on stress relief measures: a field experiment. J Environ Psychol 38:1-9. https://doi.org/10.1016/j.jenvp.2013.12.005

Tzoulas K, Korpela K, Venn S, Yli-Pelkonen V, Kazmierczak A, Niemela J, James P (2007) Promoting ecosystem and human health in urban areas using green infrastructure: a literature review. Landsc Urban Plan 81(3):167-178. https://doi.org/10.1016/j.landurbplan.2007.02.001

Ulrich RS (1984) View through a window may influence recovery from surgery. Science 224(4647):420-421

Ulrich RS, Simons RF, Losito BD, Fiorito E, Miles MA, Zelson M (1991) Stress recovery during exposure to natural and urban environments. J Environ Psychol 11(3):201-230. https://doi. org/10.1016/S0272-4944(05)80184-7 
United Nations (1992) Convention on biological diversity. United Nations, Rio de Janeiro. https:// www.cbd.int/doc/legal/cbd-en.pdf

Valtorta NK, Kanaan M, Gilbody S, Ronzi S, Hanratty B (2016) Loneliness and social isolation as risk factors for coronary heart disease and stroke: systematic review and meta-analysis of longitudinal observational studies. Heart 102(13):1009-1016. https://doi.org/10.1136/ heartjnl-2015-308790

van den Berg M, Wendel-Vos W, van Poppel M, Kemper H, van Mechelen W, Maas J (2015) Health benefits of green spaces in the living environment: a systematic review of epidemiological studies. Urban For Urban Gree 14(4):806-816. https://doi.org/10.1016/j.ufug.2015.07.008

Ward Thompson C (2013) Activity, exercise and the planning and design of outdoor spaces. J Environ Psychol 34:79-96. https://doi.org/10.1016/j.jenvp.2013.01.003

Watts N, Adger WN, Agnolucci P, Blackstock J, Byass P, Cai W, Chaytor S, Colbourn T, Collins M, Cooper A, Cox PM, Depledge J, Drummond P, Ekins P, Galaz V, Grace D, Graham H, Grubb M, Haines A, Hamilton I, Hunter A, Jiang X, Li M, Kelman I, Liang L, Lott M, Lowe R, Luo Y, Mace G, Maslin M, Nilsson M, Oreszczyn T, Pye S, Quinn T, Svensdotter M, Venevsky S, Warner K, Xu B, Yang J, Yin Y, Yu C, Zhang Q, Gong P, Montgomery H, Costello A (2015) Health and climate change: policy responses to protect public health. Lancet 386(10006):18611914. https://doi.org/10.1016/S0140-6736(15)60854-6

Wheater CP (1999) Urban habitats. Habitat guides. Routledge, London

Wheater CP, Potts E, Shaw EM, Perkins C, Smith H, Casstles H, Cook PA, Bellis MA (2007) Urban parks and public health: exploiting a resource for healthy minds and bodies. Liverpool John Moores University. http://www.cph.org.uk/wp-content/uploads/2012/08/urban-parksand-public-health-exploiting-a-resource-for-healthy-minds-and-bodies.pdf

Wilmot EG, Edwardson CL, Achana FA, Davies MJ, Gorely T, Gray LJ, Khunti K, Yates T, Biddle SJH (2012) Sedentary time in adults and the association with diabetes, cardiovascular disease and death: systematic review and meta-analysis. Diabetologia 55(11):2895-2905. https://doi. org/10.1007/s00125-012-2677-z

Wilson EO (1984) Biophilia. Harvard University Press, Cambridge

Wolch JR, Byrne J, Newell JP (2014) Urban green space, public health, and environmental justice: the challenge of making cities 'just green enough'. Landsc Urban Plan 125:234-244. https:// doi.org/10.1016/j.landurbplan.2014.01.017

Wood CL, Lafferty KD, DeLeo G, Young HS, Hudson PJ, Kuris AM (2014) Does biodiversity protect humans against infectious disease? Ecology 95(4):817-832. https://doi.org/10.1890/13-1041.1

World Health Organisation (2016) Urban green spaces and health: a review of evidence. World Health Organisation Regional Office for Europe, Copenhagen

Zhang JW, Piff PK, Iyer R, Koleva S, Keltner D (2014) An occasion for unselfing: beautiful nature leads to prosociality. J Environ Psychol 37:61-72. https://doi.org/10.1016/j.jenvp.2013.11.008

Open Access This chapter is licensed under the terms of the Creative Commons Attribution 4.0 International License (http://creativecommons.org/licenses/by/4.0/), which permits use, sharing, adaptation, distribution and reproduction in any medium or format, as long as you give appropriate credit to the original author(s) and the source, provide a link to the Creative Commons license and indicate if changes were made.

The images or other third party material in this chapter are included in the chapter's Creative Commons license, unless indicated otherwise in a credit line to the material. If material is not included in the chapter's Creative Commons license and your intended use is not permitted by statutory regulation or exceeds the permitted use, you will need to obtain permission directly from the copyright holder.

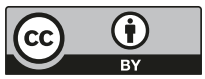

